\title{
Respiratory costs of woody tissues in a Quercus pyrenaica coppice
}

\author{
Roberto Luis Salomón ${ }^{(1-2)}$, \\ Jesús Rodríguez-Calcerrada ${ }^{(1)}$, \\ Luis Gil (1), \\ María Valbuena-Carabaña ${ }^{(1)}$
}

\begin{abstract}
Long-term coppicing leads to the development of massive root systems. A disproportionate carbon investment in root maintenance has been pointed as a cause of the widespread decline of abandoned coppices. We aimed at assessing how coppicing has influenced root and shoot development and related carbon loss ascribed to maintenance of woody tissues in Quercus pyrenaica. For this goal, results from published studies on root dynamics, woody biomass and respired $\mathrm{CO}_{2}$ fluxes in an abandoned $Q$. pyrenaica coppice were integrated and extended to quantify overall respiratory expenditures of above- and below-ground woody organs. Internal and external $\mathrm{CO}_{2}$ fluxes together with soil $\mathrm{CO}_{2}$ efflux were monitored in eight stems from one clone across a growing season. Stems and roots were later harvested to quantify the functional biomass and scale up root and stem respiration $\left(R_{\mathrm{R}}\right.$ and $R_{\mathrm{s}}$, respectively) to the clone and stand levels. Below- and above-ground biomass was roughly equal. However, the root-to-shoot ratio of respiration $\left(R_{R} / R_{S}\right)$ was generally below one. Relatively higher $R_{\mathrm{S}}$ suggests enhanced metabolic activity aboveground during the growing season, and highlights an unexpected but substantial contribution of $R_{\mathrm{S}}$ to respiratory carbon losses. Moreover, soil and stem $\mathrm{CO}_{2}$ efflux to the atmosphere in $Q$. pyrenaica fell in the upper range of reported rates for various forest stands distributed worldwide. We conclude that both $R_{\mathrm{S}}$ and $R_{\mathrm{R}}$ represent an important carbon sink in this $Q$. pyrenaica abandoned coppice. Comparatively high energetic costs in maintaining multiple stems per tree and centennial root systems might constrain aboveground performance and contribute to coppice stagnation.
\end{abstract}

Keywords: Carbon Loss, $\mathrm{CO}_{2}$ Fluxes, Coppice Stagnation, Oak, Resprouting Species, Root Respiration, Stem Respiration

and consequently, hindered application of alternative management plans. Due to the value of coppiced stands of Mediterranean oak species, silviculture faces the crucial challenge of finding new alternative uses for these abandoned coppices (Cañellas et al. 2004, Bravo et al. 2008). Attempts to conversion into high forests via thinning have not been successful to date, partly due to the lack of a comprehensive understanding of the physiological mechanisms underpinning tree stagnation (Salomón et al. 2017).

Disproportionate respiratory costs of large root systems grown after centennial wide distribution and significant ecological ductivity, absence of sexual regeneration,

Quercus pyrenaica Willd. is a vigorous tensively coppiced for firewood, charc la Torre 2006). Due to the appearance of new energy sources and rural exodus that occurred in the 1970s, coppicing has mostly , and symptoms of decline stem growth, branch dieback, and sca abandoned stands (Serrada \& Bravo 2012). Coppice stagnation entails ecologic, economic and social problems, namely in-

(1) Forest Genetics and Ecophysiology Research Group, E.T.S. Forestry Engineering, Technical University of Madrid, Ciudad Universitaria s/n, 28040, Madrid (Spain); (2) Laboratory of Plant Ecology, Department of Applied Ecology and Environmental Biology, Faculty of Bioscience Engineering, Ghent University, Coupure links 653-9000 Ghent (Belgium)

@ Roberto Luis Salomón (robertoluis.salomonmoreno@ugent.be)

Received: Aug 11, 2017 - Accepted: Apr 09, 2018

Citation: Salomón RL, Rodríguez-Calcerrada J, Gil L, Valbuena-Carabaña M (2018). Respiratory costs of woody tissues in a Quercus pyrenaica coppice. iForest 11: 437-441. - doi: 10.3832/ifor2599-011 [online 2018-06-18]

Communicated by: Giorgio Matteucci coppicing have been suggested as a potential driver of Q. pyrenaica decay (Bravo et al. 2008), but assessments on carbon expenditures have not been essayed to date. Quantification of the relative weight of respiratory carbon sinks for the plant is crucial for a better understanding of tree carbon budgets (Waring et al. 1998, Amthor 2000, Rambal et al. 2014). Notwithstanding, our comprehension of respiratory processes, particularly of woody organs, is limited compared to our knowledge of photosynthesis (Guidolotti et al. 2013, Rambal et al. 2014, Huntingford et al. 2017). In resprouting deciduous species, nonstructural carbohydrates are stored in large amounts in woody organs (Bond \& Midgley 2001) that can contain a large portion of living parenchyma (Rodríguez-Calcerrada et al. 2015). The penalty in terms of respiratory carbon loss associated to the maintenance of these storage tissues (Landhäusser \& Lieffers 2002, Drake et al. 2009) could be of particular relevance in carbon budgets of root-resprouting Q. pyrenaica. Long lasting coppicing might lead to massive systems of living roots (Salomón et al. 2016a, Vrška et al. 2016) that store but also consume a large portion of carbohydrates assimilated aboveground.

To better understand the role of respiratory carbon loss in Q. pyrenaica decay, we gathered and extended previous published 
work on Q. pyrenaica biomass and respiration of woody tissues (Salomón et al. 2015, 2016a, 2016b, 2016c) to scale up stem and root respiration ( $R_{S}$ and $R_{R}$, respectively) to the tree and stand levels. We aimed at comparing respiratory expenditures (i) between above- and below-ground woody organs across one growing season, and (ii) in relation to data gathered from various forests to provide an insight of the magnitude of carbon invested for woody tissue respiration in Q. pyrenaica coppices. We expect $R_{S}$ and particularly $R_{R}$ to be important carbon sinks for the plant (i.e., from the plant perspective), and therefore high $R_{R} / R_{S}$ ratios as well as woody tissue respiration rates relative to other forest stands.

\section{Materials and methods}

To estimate respiratory carbon loss of woody organs in a coppice system of Q. pyrenaica, we reviewed our previous work on Q. pyrenaica root development and biomass (Salomón et al. 2016a), and internal and external stem $\mathrm{CO}_{2}$ fluxes (Salomón et al. 2015, 2016b, 2016c), together with unpublished data of soil $\mathrm{CO}_{2}$ efflux. These studies were performed in a one-hectare experimental plot located in the Monte Matas de Valsaín (Segovia, Spain) at an altitude of $1140 \mathrm{~m}$ a.s.l. Climate is sub-Mediterranean with an average annual rainfall and temperature of $885 \mathrm{~mm}$ and $10{ }^{\circ} \mathrm{C}$, respectively. It consists on a monospecific onestoried regular coppice of Q. pyrenaica with a stand density of 781 stems ha $^{-1}$. The forest has been subjected to coppicing since at least the XII century, and traditional management was abandoned in the 1970s. Stems within the plot were geo-referenced and leaves collected for genetic analyses to delineate the commonly inconspicuous clonal structure of $Q$. pyrenaica coppiced stands. Note that Q. pyrenaica is a root resprouting species, hence one clone can be constituted by several stems located far away (dozens of meters) from each other (Valbuena-Carabaña \& Gil 2017). The clonal assignment of stems was based on nuclear microsatellite molecular markers (Valbue-
na-Carabaña \& Gil 2013 - see Fig. 1 in Salomón et al. 2015). Data on woody tissue respiration was collected from the eight stems belonging to a single clonal genotype (clone). Four 24-h measurement campaigns were conducted across the growing season of 2013, at the end of which stems and roots were harvested for biomass quantification and scaling up of $R_{\mathrm{S}}$ and $R_{\mathrm{R}}$ to the clone and stand levels. The root system was hydraulically excavated with a highpressure water pump down to $1 \mathrm{~m}$ depth over an area of $81 \mathrm{~m}^{2}$ (Fig. 1). Biomass was partitioned into leaves, branches, stems, taproots, coarse roots and fine roots. Woody biomass was further partitioned into bark, sapwood and heartwood tissues from allometric equations adjusted by means of exhaustive sampling of branches, stems, taproots and coarse roots. Leaf area index (LAI) was estimated from measurements of specific leaf area of sampled leaves and total leaf biomass. Further details on stand characteristics, excavation methodology, and above- and belowground biomass measurements can be seen in Salomón et al. (2016a).

Stem $\mathrm{CO}_{2}$ efflux to the atmosphere $\left(E_{\mathrm{A}}\right)$ was measured in every stem with a portable infrared gas analyzer (LI-6400 ${ }^{\oplus}$, Li-Cor Inc., Lincoln, NE, USA) and a soil chamber (LI-6400-09 ${ }^{\oplus}$ ) using PVC collars attached to the stems. Stem $E_{\mathrm{A}}$ measured on a surface area basis $\left(E_{\mathrm{A}(\mathrm{s})}\right)$ was expressed on a volume basis $\left(E_{A(V)}-\right.$ eqn. 1):

$$
\begin{aligned}
& E_{A(V)}=E_{A(S)} \frac{S}{V}= \\
& =E_{A(S)} \frac{2 \pi r_{h+l} L}{\pi\left(r_{h+l}^{2}-r_{h}^{2}\right) L}=E_{A(S)} \frac{2 r_{h+l}}{\left(r_{h+l}^{2}-r_{h}^{2}\right)}
\end{aligned}
$$

where $S$ and $V$ are the axial surface area and the volume of living tissues (bark and sapwood) of the stem segment, respectively; $r_{h}$ and $r_{h+1}$ denote the radius of heartwood and heartwood plus living tissues, respectively, and $L$ is the vertical length of the stem segment (Salomón et al. 2016c). Stem respiration $\left(R_{S}\right)$ was estimated as the sum of $E_{\mathrm{A}(\mathrm{V})}$ and the internal $\mathrm{CO}_{2}$ flux through xylem $\left(F_{\mathrm{T}}\right)$ as $R_{\mathrm{S}}=E_{\mathrm{A}}+F_{\mathrm{T}}$ (adapted from McGuire \& Teskey 2004). $F_{\mathrm{T}}$ was calculated as a function of the sap flux and the vertical gradient of $\mathrm{CO}_{2}$ dissolved in sap solution ( $\left.\operatorname{sap}\left[\mathrm{CO}_{2}{ }^{*}\right]\right)$. Sap flux density was measured using Granier-type thermal dissipation probes, and sap $\left[\mathrm{CO}_{2}{ }^{*}\right]$ was estimated from measurements of xylem $\left[\mathrm{CO}_{2}\right]$ in the gas phase, sap temperature, and sap $\mathrm{pH}$ in each stem applying Henry's law. Briefly, xylem $\left[\mathrm{CO}_{2}\right]$ was measured with solid non-dispersive infrared (NDIR) $\mathrm{CO}_{2}$ sensors (model GMM221 ${ }^{\oplus}$, Vaisala, Helsinki, Finland) inserted into the stem above and below the stem collar. Stem temperature was measured with type-T thermocouples inserted $5 \mathrm{~cm}$ away from the NDIR probe. Sap $\mathrm{pH}$ was measured with a micro-pH electrode and a portable $\mathrm{pH}$ meter (Crison, Barcelona, Spain) on sap samples expressed from detached twigs using a pressure chamber (see Salomón et al. 2016b for further details). Overall $E_{\mathrm{A}}, F_{\mathrm{T}}$ and $R_{\mathrm{S}}$ at the clone level were estimated by aggregating $E_{\mathrm{A}}, F_{\mathrm{T}}$ and $R_{\mathrm{S}}$ scaled up for each stem (and their branches) according to their corresponding volume of living woody biomass. Aboveground clonal respiratory fluxes were eventually expressed on a soil surface area basis taking into account the clonal surface extension.

Soil $\mathrm{CO}_{2}$ efflux $\left(E_{\mathrm{S}}\right)$ was measured with a portable infrared gas analyzer and a soil chamber using soil PVC collars (see Salomón et al. 2015 for detailed methodology). Unpublished data from four soil collars located below the canopy of the eight monitored stems were averaged to obtain clonal $E_{s}$ on a soil area basis $\left(\mathrm{m}^{2}\right)$. Since roots barely extended beyond the excavated area $\left(81 \mathrm{~m}^{2}\right)$, a buffer of $0.63 \mathrm{~m}$ was added to estimate the clone extension (102 $\mathrm{m}^{2}$ ). This buffer distance was chosen to meet actual stand density ( 8 stems in 102 $\mathrm{m}^{2}=784$ stems ha- ${ }^{-1}$ ) and scale up results to the stand level. Root-respired $\mathrm{CO}_{2}$ diffusing to the atmosphere through soil $\left(E_{S-R o o t}\right)$ was estimated from $E_{\mathrm{s}}$ measurements and the relative contribution of autotrophic respiration to $E_{\mathrm{s}}$. Seasonality of root autotrophic contribution to $E_{\mathrm{s}}$ was obtained

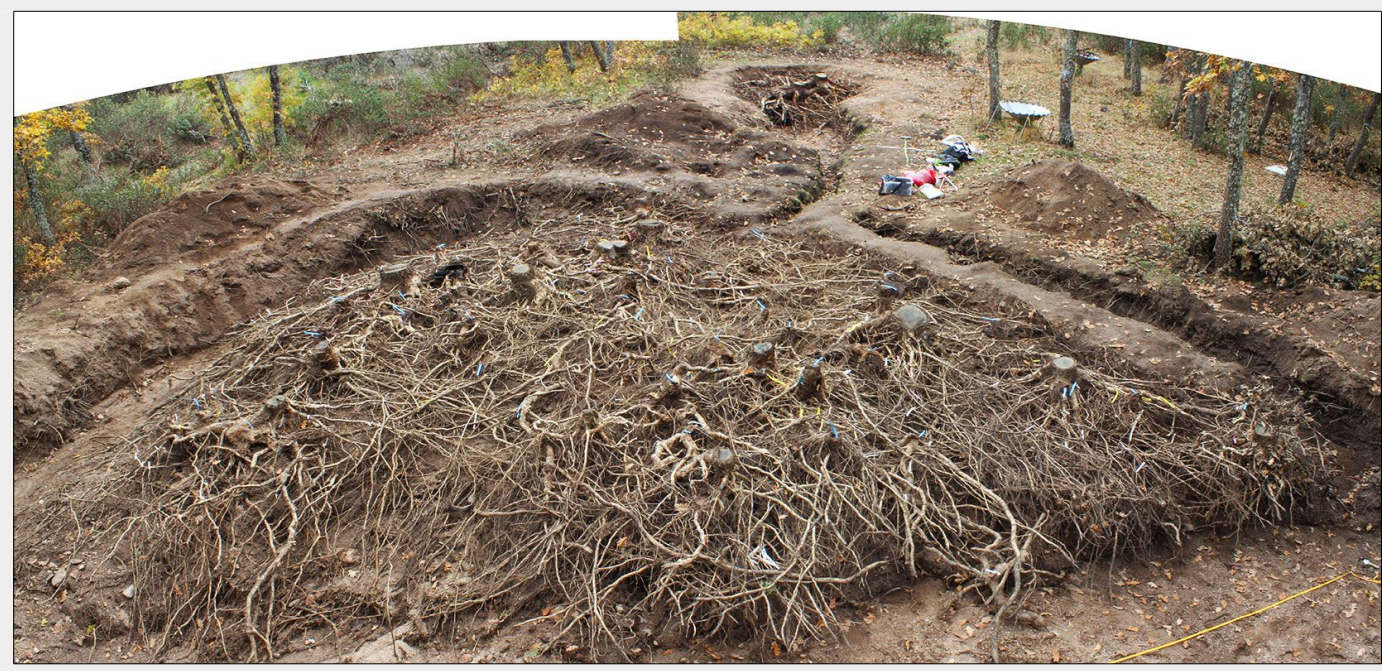

Fig. 1 - Root systems of two hydraulically excavated clones of Quercus pyrenaica located in the Monte Matas de Valsaín (Segovia, Spain). The root system of the large clone surveyed in this study (lower part of the photograph) covered at least 81 $\mathrm{m}^{2}$. Before harvesting, the clone was composed by eight stems connected through root grafts and parental roots. 
from two studies in a Mediterranean Quercus cerris coppice cut one (Rey et al. 2002) and 17 (Tedeschi et al. 2006) years before $E_{\mathrm{s}}$ measurements. Spring contributions reported in these studies were attributed to the first measurement campaign (DOY 143144), summer contributions to the second (DOY 183-184) and third (DOY 218-219) campaigns, and autumn contributions to the fourth campaign (DOY 266-267). To account for $F_{T}$ on $R_{R}$ estimates $\left(R_{R}=E_{S-\text { ROOT }}+F_{T}\right.$ - Aubrey \& Teskey 2009), internal and external $\mathrm{CO}_{2}$ fluxes were measured at the base of the stem $(0.1 \mathrm{~m})$.

To compare $E_{S}, R_{R}$ and $R_{S}$ averaged over the growing season within the monitored clone, ANOVA and pairwise comparisons were performed in $\mathrm{R}$ software (version 3.4.0). Respiratory fluxes at the stand level from 15 sites were gathered (Tab. S1 in Supplementary material) to evaluate the relative magnitude of respiratory costs of the surveyed Q. pyrenaica coppice. Inter-site statistical comparisons were not performed because only one site was surveyed in this study.

\section{Results and discussion}

Seasonal and diel variation in $E_{\mathrm{A}}, F_{\mathrm{T}}$ and $E_{\mathrm{S}}$ on a soil area basis are shown in Fig. 2. The contribution of $F_{\mathrm{T}}$ to aboveground $R_{\mathrm{S}}$ was less than 10\% (Salomón et al. 2016c), whereas $F_{\mathrm{T}}$ belowground was less than $2 \%$ of $E_{\text {S-Rоoт }}$ (Salomón et al. 2015). The modest contribution of axial $\mathrm{CO}_{2}$ transport to total respiration rates is explained by the low xylem $\left[\mathrm{CO}_{2}\right]$ observed in Q. pyrenaica, generally lower than $1 \%$. This concentration is about one order of magnitude lower than that reported for other tree species using this methodology (Teskey et al. 2008). The limited build-up of $\mathrm{CO}_{2}$ in the xylem was partly ascribed to the low resistance to radial $\mathrm{CO}_{2}$ diffusion, likely related to the poor plant water status of species distributed across drought-prone regions (Salomón et al. 2016b). Averaged over the growing season, $E_{S}\left(38.9 \mathrm{~mol} \mathrm{CO}_{2}\right.$ clone $^{-1}$ day $\left.^{-1}\right)$ was greater than $R_{\mathrm{S}}\left(11.7 \mathrm{~mol} \mathrm{CO}_{2}\right.$ clone $^{-1}$ day $\left.^{-1}\right)$ and $R_{R}\left(8.5 \mathrm{~mol} \mathrm{CO}_{2}\right.$ clone $^{-1}$ day $^{-1}-\mathrm{P}<0.001$; Tab. 1, Fig. 2), being $R_{S}$ and $R_{R}$ not significantly different $(P>0.10)$. Due to the magnitude of $E_{s}$, the contribution of autotrophic respiration to $E_{s}$ substantially determined the root-to-shoot ratio of respiration $\left(R_{R} / R_{S}\right)$. To illustrate this, a contribution of $R_{R}$ to $E_{S}$ ranging between 14 and $27 \%$ (Rey et al. 2002, Tedeschi et al. 2006 - data reported for a Mediterranean oak coppice at different states of maturity) yielded $R_{R} / R_{S}$ ratios ranging between 0.42 and 1.18 across the growing season (Tab. 1). Alternatively, if heterotrophic and autotrophic contributions to $E_{\mathrm{s}}$ were considered equal, as generally assumed for different forest biomes (Hanson et al. 2000, Aubrey \& Teskey 2009), $R_{R} / R_{S}$ would reach values ranging from 1.36 to 2.18 .

Above- and below-ground functional woody biomass (bark and sapwood) was similar in the surveyed clone: $1026 \mathrm{Kg}$

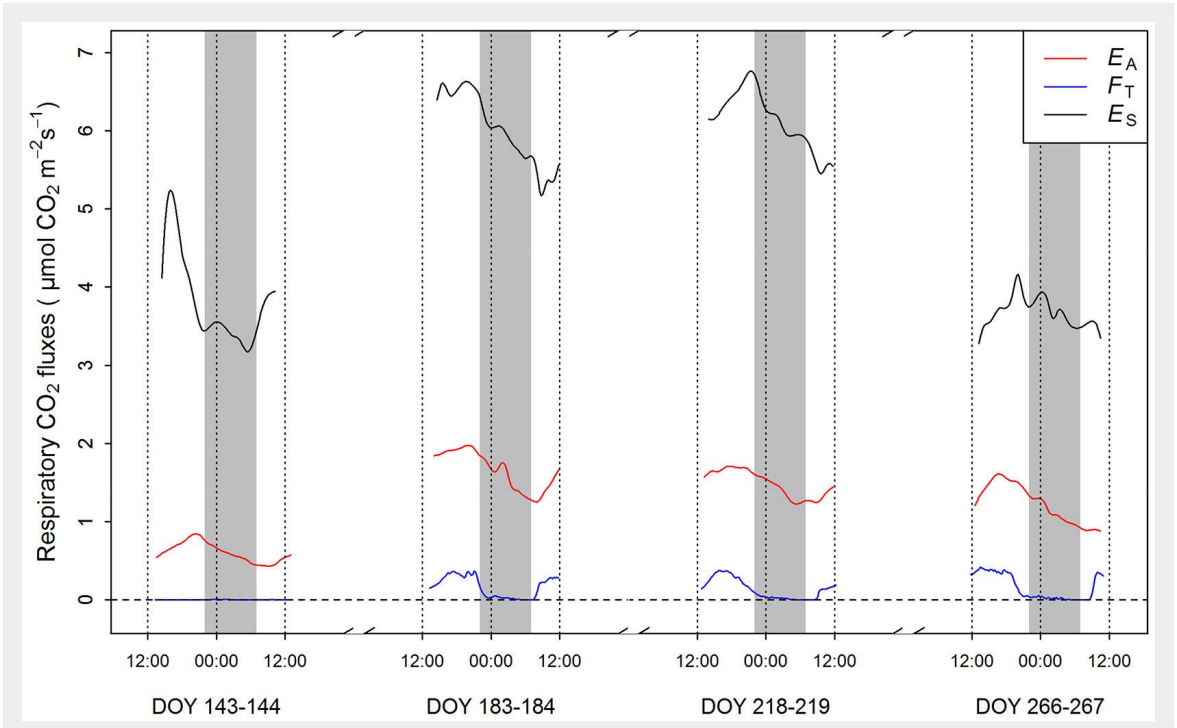

Fig. 2 - Diel variations in stem $\mathrm{CO}_{2}$ efflux to the atmosphere $\left(E_{\mathrm{A}}\right)$, stem internal $\mathrm{CO}_{2}$ transport through xylem $\left(F_{T}\right)$ and soil $\mathrm{CO}_{2}$ efflux $\left(E_{\mathrm{S}}\right)$ on four dates over the growing season in an abandoned coppice of Quercus pyrenaica. Fluxes registered from one stem segment and one soil collar intensively monitored $\left(18\right.$ times day $\left.{ }^{-1}\right)$ are shown. Additional stem segments and collars used to average $E_{\mathrm{A}}, F_{\mathrm{T}}$ and $E_{\mathrm{S}}$ are not displayed in this figure as they were monitored less intensively $\left(4\right.$ times day $\left.{ }^{-1}\right) . E_{A}$ and $F_{T}$ on a volume basis was obtained from previous work (Salomón et al. 2016c) and expressed on a soil area basis for comparison with $E_{\mathrm{s}}$. Shaded areas indicate night-time.

aboveground and $972 \mathrm{Kg}$ belowground (Salomón et al. 2016a). Consequently, seasonal deviations of $R_{R} / R_{S}$ from unity reflected differences in the metabolic activity between below- and above-ground organs over time. $R_{R} / R_{S}$ ratio above one was uniquely observed during spring (Tab. 1), likely explained by an earlier growth of roots relative to stems (López et al. 2001), particularly by intense fine root growth and belowground cambial activity at this time of the year (Courty et al. 2007). The decrease in $R_{R} / R_{S}$ observed onward (ratios below one) resulted from the moderate root activity relative to the intensification of aboveground metabolism, namely stem growth, leaf development and phloem transport. Predominant $R_{R} / R_{S}$ ratios below

one along the growing season evidenced an unexpected large weight of aboveground woody tissue respiration as a carbon sink for the plant. The accumulation of woody biomass in stems and branches in this over-aged coppice (cut for the last time around 1967), together with the remarkably high portion of living parenchyma observed in Q. pyrenaica stems (Rodríguez-Calcerrada et al. 2015) may contribute to the high respiratory costs of woody organs aboveground.

Respiratory fluxes at the stand level, and extrapolated to the whole year, were compared with those reported for several forest sites (see Tab. s1 in Supplementary material for details on the extrapolation). Average $E_{S}$ and $E_{\mathrm{A}}$ across 15 stands were 776

Tab. 1 - Above- and below-ground respiratory fluxes in an eight-stemmed clone of Quercus pyrenaica. Stem $\mathrm{CO}_{2}$ efflux to the atmosphere $\left(E_{\mathrm{A}}\right)$, soil $\mathrm{CO}_{2}$ efflux $\left(E_{\mathrm{S}}\right)$, and stem and root respiration ( $R_{S}$ and $R_{R}$, respectively) were measured during four 24-h campaigns throughout 2013 growing season. (a): $R_{\mathrm{S}}$ was estimated as the sum of $E_{\mathrm{A}}$ and the internal $\mathrm{CO}_{2}$ flux through xylem $\left(F_{\mathrm{T}}\right)$. (b): $R_{\mathrm{R}}$ was estimated from $E_{S}$ measurements and the contribution of autotrophic respiration to $E_{s}$. Autotrophic contribution to $E_{S}$ was obtained from two reports of a Mediterranean coppice of Quercus cerris cut one (Rey et al. 2002) and 17 years (Tedeschi et al. 2006) before measurements. Estimations of $R_{R}$ and $R_{R} / R_{S}$ ratios from contributions reported in both studies (recently coppiced vs mature stand) are shown in left and right sub-columns, respectively. $F_{T}$ was neglected in $R_{R}$ due to its low contribution ( $<2 \%$ ).

\begin{tabular}{|c|c|c|c|c|c|}
\hline \multirow{2}{*}{$\begin{array}{l}\text { Campaign } \\
\text { DOY }\end{array}$} & $E_{\mathrm{A}}$ & $R_{\mathrm{S}}{ }^{(\mathrm{a})}$ & $E_{\mathrm{S}}$ & $R_{\mathrm{R}}{ }^{(\mathrm{b})}$ & \multirow{2}{*}{$R_{\mathrm{R}} / R_{\mathrm{S}}$} \\
\hline & \multicolumn{4}{|c|}{$\left(\mathrm{mol} \mathrm{CO}_{2}\right.$ clone $^{-1}$ day $\left.^{-1}\right)$} & \\
\hline $143-144$ & 6.16 & 6.16 & 26.83 & 5.03 vs 7.25 & 0.82 vs 1.18 \\
\hline $183-184$ & 12.28 & 13.13 & 52.14 & 11.32 vs 11.70 & 0.86 vs 0.89 \\
\hline $218-219$ & 15.63 & 16.45 & 43.72 & 9.49 vs 9.82 & 0.58 vs 0.60 \\
\hline $266-267$ & 10.54 & 11.23 & 32.76 & 8.82 vs 4.68 & 0.79 vs 0.42 \\
\hline Mean & 11.15 & 11.74 & 38.86 & 8.66 vs 8.36 & 0.76 vs 0.77 \\
\hline
\end{tabular}


and $162 \mathrm{~g} \mathrm{C} \mathrm{m}^{-2}$ year $^{-1}$, respectively, whereas these values increased up to 1164.2 and $297.0 \mathrm{~g} \mathrm{C} \mathrm{m}^{-2}$ year $^{-1}$ in the surveyed Q. pyrenaica coppice (Tab. S1). That is, $E_{S}$ and $E_{A}$ were 1.5 and 1.8 times higher in this study, suggesting greater carbon losses from soil and stem respiration. These ratios could be substantially reduced, however, if xylem transport of respired $\mathrm{CO}_{2}$ was accounted for (Aubrey \& Teskey 2009) in the 15 forest stands. Leaf area index, a key ecophysiological determinant of carbon gas exchange at the canopy (Bréda 2003), was additionally considered for comparison. LAl in our site was 3.8, a value that falls within the reported range for the species (Hernández-Santana et al. 2009) and the genus Quercus (Bréda 2003). The slightly low LAl relative to that averaged across different forest types (4.2 - Tab. S1 in Supplementary material) does not suggest a greater potential for carbon assimilation. Taken together, these rough comparisons suggest a strong carbon sink for the plant associated to respiratory processes that do not scale with the carbon input within the surveyed Q. pyrenaica coppice.

To summarize, the relative importance of $R_{R}$ and $R_{S}$ as carbon sinks for the plant shifted along the growing season in accordance to the root and stem phenology and metabolic activity. $R_{R} / R_{S}$ ratios lower than one point to an unexpected importance of aboveground woody tissue respiration in carbon budgets of Q. pyrenaica coppices. Large carbon losses via soil and stem respiration relative to those observed in several forest types supports the hypothesis of an imbalance between carbon sources and sinks, contributing to the decline of abandoned coppices (Corcuera et al. 2006, Salomón et al. 2015, 2016a). Nonetheless, these conclusions should be handled with caution due to the lack of data on carbon assimilation, and the limited sample size of the study, largely constrained by the laborious task of root excavation. Firstly, temporal patterns of leaf carbon exchange should be analyzed in detail to gain a comprehensive perspective of tree carbon budgets and to better address the role of a potential root-to-shoot physiological imbalance in Q. pyrenaica coppice decline. Secondly, a greater number of monitored individuals as well as soil collars within the plot and across longer periods would improve spatial and temporal upscaling of respiratory fluxes. In this line, comparisons between coppiced and non-coppiced sites would provide stronger empirical support to the hypothesis that historical coppicing leads to massive root development and constrained aboveground performance.

\section{List of abbreviations}

$E_{A}$, stem $\mathrm{CO}_{2}$ efflux to the atmosphere; $E_{A}$ LEAF, foliage $\mathrm{CO}_{2}$ efflux to the atmosphere; $E_{S}$, soil $\mathrm{CO}_{2}$ efflux; $E_{S \text {-Root, }}$ root-respired $\mathrm{CO}_{2}$ that diffused to the atmosphere through soil; $F_{\mathrm{T}}$, internal $\mathrm{CO}_{2}$ flux through xylem; $R_{\mathrm{R}}$, root respiration; $R_{s}$, stem respiration

\section{Acknowledgements}

We are grateful to Javier Donés (Centro de Montes y Aserradero de Valsaín) for economic and logistical support. We also thank Elena Zafra, Guillermo González, César Otero, Manuel Iglesias, Paula Guzmán, Aida Rodríguez, Jose Carlos Miranda, Rosa Ana López, Eva Miranda and Matías Millerón for their enthusiastic help with field work. This work was funded by the Comunidad de Madrid through CAM P2009/AMB-1668 and S2013/MAE-2760 projects and by the Organismo Autónomo de Parques Nacionales through the PPNN 1148/2014 project. Roberto L. Salomón was supported by a Ph.D. scholarship from the Universidad Politécnica de Madrid.

\section{References}

Amthor J (2000). The McCree-de Wit-Penning de Vries-Thornley respiration paradigms: 30 years later. Annals of Botany 86: 1-20. - doi: 10.1006/ anbo.2000.1175

Aubrey DP, Teskey RO (2009). Root-derived $\mathrm{CO}_{2}$ efflux via xylem stream rivals soil $\mathrm{CO}_{2}$ efflux. New Phytologist 184: 35-40. - doi: 10.1111/j.14698137.2009.02971.x

Bond WJ, Midgley JJ (2001). Ecology of sprouting in woody plants: the persistence niche. Trends in Ecology and Evolution 16: 45-51. - doi: 10.1016/S0169-5347(00)02033-4

Bravo JA, Roig S, Serrada R (2008). Selvicultura en montes bajos y medios de Quercus ilex L., Q. pyrenaica Willd. y Q. faginea Lam. [Silviculture in Quercus ilex L., Q. pyrenaica Willd. and Q. faginea Lam. coppices]. In: "Compendio de Selvicultura aplicada en España [Compendium of applied silviculture]" (R Serrada, G Montero eds). Instituto Nacional de Investigación y Tecnnología Agraria y Alimentaria, Madrid, Spain, pp. 657-744. [in Spanish]

Bréda N (2003). Ground-based measurements of leaf area index: a review of methods, instruments and current controversies. Journal of Experimental Botany 54: 2403-2417. - doi: 10.1093/ jxb/erg263

Cañellas I, Del Rio M, Roig S, Montero G (2004). Growth response to thinning in Quercus pyrenaica Willd. coppice stands in Spanish central mountain. Annals of Forest Science 61: 243-250. doi: 10.1051/forest:2004017

Corcuera L, Camarero JJ, Sisó S, Gil-Pelegrín E (2006). Radial-growth and wood-anatomical changes in overaged Quercus pyrenaica coppice stands: functional responses in a new Mediterranean landscape. Trees 20: 91-98. - doi: 10.1007/s00468-005-0016-4

Courty PE, Bréda N, Garbaye J (2007). Relation between oak tree phenology and the secretion of organic matter degrading enzymes by Lactarius quietus ectomycorrhizas before and during bud break. Soil Biology and Biochemistry 39: 1655-1663. - doi: 10.1016/j.soilbio.2007.01.017 Drake PL, Mendham DS, White DA, Ogden GN (2009). A comparison of growth, photosynthetic capacity and water stress in Eucalyptus globulus coppice regrowth and seedlings during early development. Tree Physiology 29: 663-674. - doi: 10.1093/treephys/tppoo6

Guidolotti G, Rey A, D’Andrea E, Matteucci G, De Angelis $P$ (2013). Effect of environmental vari- ables and stand structure on ecosystem respiration components in a Mediterranean beech forest. Tree Physiology 33: 960-972. - doi: 10.1093/treephys/tpto65

Hanson PJ, Edwards NT, Garten CT, Andrews JA (2000). Separating root and soil microbial contributions to soil respiration: A review of methods and observations. Biogeochemistry 48: 115146. - doi: 10.1023/A:1006244819642

Hernández-Santana V, Martínez-Vilalta J, Martínez-Fernández J, Williams M (2009). Evaluating the effect of drier and warmer conditions on water use by Quercus pyrenaica. Forest Ecology and Management 258: 1719-1730. - doi: 10.1016/j. foreco.2009.07.038

Huntingford C, Atkin OK, Martinez de la Torre A, Mercado LM, Heskel MA, Harper AB, Bloomfield KJ, Sullivan OS, Reich PB, Whythers KR, Butler EE, Chen M, Griffin KL, Meir Tjoelker $\mathrm{P}$ MG, Turnbull MH, Sitch S, Wiltshire A, Malhi Y (2017). Implications of improved representations of plant respiration in a changing climate. Nature Communications 8 (1): 184. - doi: 10.103 8/s41467-017-01774-z

Landhäusser SM, Lieffers VJ (2002). Leaf area renewal, root retention and carbohydrate reserves in a clonal tree species following aboveground disturbance. Journal of Ecology 90: 658-665. - doi: 10.1046/j.1365-2745.2002.00699. $\mathrm{x}$

López B, Sabate S, Gracia CA (2001). Annual and seasonal changes in fine root biomass of a Quercus ilex L. forest. Plant and Soil 230: 125134. - doi: 10.1023/A:1004824719377

McGuire MA, Teskey RO (2004). Estimating stem respiration in trees by a mass balance approach that accounts for internal and external fluxes of $\mathrm{CO}_{2}$. Tree Physiology 24: 571-578. - doi: 10.109 3/treephys/24.5.571

Rambal S, Lempereur M, Limousin JM, MartinStPaul NK, Ourcival JM, Rodríguez-Calcerrada J (2014). How drought severity constrains gross primary production (GPP) and its partitioning among carbon pools in a Quercus ilex coppice? Biogeosciences 11: 6855-6869. - doi: 10.5194/bg11-6855-2014

Rey A, Pegoraro E, Tedeschi V, De Parri I, Jarvis $P G$, Valentini $R$ (2002). Annual variation in soil respiration and its components in a coppice oak forest in Central Italy. Global Change Biology 8: 851-866. - doi: 10.1046/j.1365-2486.2002. $00521 . x$

Rodríguez-Calcerrada J, López R, Salomón R, Gordaliza G, Valbuena-Carabaña M, Oleksyn J, Gil L (2015). Stem $\mathrm{CO}_{2}$ efflux in six co-occurring tree species: underlying factors and ecological implications. Plant, Cell and Environment 38: 1104-1115. - doi: 10.1111/pce.12463

Ruiz de la Torre J (2006). Flora Mayor [Major Flora]. Organismo Autónomo de Parques Nacionales, Madrid, Spain, pp. 1756. [in Spanish] Salomón R, Rodríguez-Calcerrada J, Zafra E, Morales-Molino C, Rodríguez-García A, González-Doncel I, Oleksyn J, Zytkowiak R, López R, Miranda JC, Gil L, Valbuena-Carabaña M (2016a). Unearthing the roots of degradation of Quercus pyrenaica coppices: a root-to-shoot imbalance caused by historical management? Forest Ecology and Management 363: 200-211. doi: 10.1016/j.foreco.2015.12.040

Salomón R, Valbuena-Carabaña M, Rodríguez- 
Calcerrada J, Aubrey D, McGuire M, Teskey R, Gil L, González-Doncel I (2015). Xylem and soil $\mathrm{CO}_{2}$ fluxes in a Quercus pyrenaica Willd. coppice: root respiration increases with clonal size. Annals of Forest Science 72: 1065-1078. - doi: 10.1007/s13595-015-0504-7

Salomón R, Valbuena-Carabaña $M$, Teskey $R$, McGuire MA, Aubrey D, González-Doncel I, Gil L, Rodríguez-Calcerrada J (2016b). Seasonal and diel variation in xylem $\mathrm{CO}_{2}$ concentration and sap $\mathrm{pH}$ in sub-Mediterranean oak stems. Journal of Experimental Botany 67: 2817-2827. doi: 10.1093/jxb/erw121

Salomón RL, Valbuena-Carabaña M, Gil L, McGuire MA, Teskey RO, Aubrey DP, GonzálezDoncel I, Rodríguez-Calcerrada J (2016c). Temporal and spatial patterns of internal and external stem $\mathrm{CO}_{2}$ fluxes in a sub-Mediterranean oak. Tree Physiology 36: 1409-1421. - doi: 10.109 3/treephys/tpw029

Salomón R, Rodríguez-Calcerrada J, Gil L, Valbuena-Carabaña M (2017). On the general failure of coppice conversion into high forest in Quercus pyrenaica stands: a genetic and physiological approach. Folia Geobotanica 52: 101-112. - doi: $10.1007 /$ s12224-016-9257-9

Serrada R, Bravo JA (2012). Mejora de la vitalidad de las masas [Improvement in stand vitality]. In: "Gestión adaptativa al cambio global en masas de Quercus mediterráneos [Adaptive management to global change in mediterranean Quercus stands]" ( $P$ Vericat, $M$ Piqué, $R$ Serrada eds). Centre Tecnològic Forestal de Catalunya, Solsona, Lleida, Spain, pp. 49-66. [in Spanish]

Tedeschi V, Rey A, Manca G, Valentini R, Jarvis PJ, Borghetti M (2006). Soil respiration in a Mediterranean oak forest at different developmental stages after coppicing. Global Change Biology 12: 110-121. - doi: 10.1111/j.1365-2486.20 05.01081.x

Teskey RO, Saveyn A, Steppe K, McGuire MA (2008). Origin, fate and significance of $\mathrm{CO}_{2}$ in tree stems. New Phytologist 177: 17-32. - doi: 10.1111/j.1469-8137.2007.02286.x

Valbuena-Carabaña M, Gil L (2013). Genetic resilience in a historically profited root sprouting oak (Quercus pyrenaica Willd.) at its southern boundary. Tree Genetics and Genomes 9: 1129-1142. - doi: 10.1007/s11295-013-0614-z
Valbuena-Carabaña M, Gil L (2017). Centenary coppicing maintains high levels of genetic diversity in a root resprouting oak (Quercus pyrenaica Willd.). Tree Genetics and Genomes. 13: 28.

Vrška T, Janík D, Pálková M, Adam D, Trochta J (2016). Below- and above-ground biomass, structure and patterns in ancient lowland coppices. iForest - Biogeosciences and Forestry 10: 23-31. - doi: 10.3832/ifor1839-009

Waring R, Landsberg J, Williams M (1998). Net primary production of forests: a constant fraction of gross primary production? Tree Physiology 18: 129-134. - doi: 10.1093/treephys/18.2.129

\section{Supplementary Material}

Tab. S1 - Stand density, leaf area index (LAI) and partitioning of annual ecosystem respiration into soil $\left(E_{S}\right)$, stem $\left(E_{A}\right)$ and leaf $\left(E_{\text {A-LeAf }}\right) \mathrm{CO}_{2}$ efflux to the atmosphere across different forest stands.

Link: Salomon_2599@supplo01.pdf 